\title{
MODEL PEMBACAAN DERRIDEAN TERHADAP A KNIGHT OF THE SEVEN KINGDOMS KARYA GEORGE R. R. MARTIN
}

\author{
Innezdhe Ayang Marhaeni \\ Universitas Gadjah Mada \\ innezdheayang@gmail.com
}

\begin{abstract}
Abstrak
Penelitian ini menganalisis novel fantasi populer berjudul A Knight of The Seven Kingdoms karya George R. R. Martin dalam perspektif Derrida, terutama pendapatnya tentang sastra sebagai institusi liberal. Dalam perspektif Derrida, penelitian ini berusaha menyelidiki afinitas dalam liberality, undecidability, iterability, khōra, dan teks itu sendiri. Dalam A Knight of The Seven Kingdoms, konsep-konsep tersebut saling memengaruhi sehingga menunjukkan aspek liberal karya sastra. Hal ini ditunjukkan melalui struktur dalam narasi A Knight of The Seven Kingdoms yang menjaga agar cerita berlangsung dinamis dan narasi tersebut, dengan kekuatan liberalnya, secara konstan menguji konteksnya sendiri untuk menghilangkan kecenderungan idealitas tertentu. Dengan demikian, identitas dan idealitas yang dianggap final kembali dipertanyakan dan dibuat tidak stabil oleh teks guna menguak lebih banyak makna serta kemungkinan yang dihasilkan.
\end{abstract}

Kata kunci: Derridean, novel fantasi, undecidability

\begin{abstract}
This study analyzes the popular fantasy novel entitled A Knight of the Seven Kingdoms by George R. R. Martin in Derrida's perspective, especially his opinion about literature as a liberal institution. In Derrida's perspective, this study seeks to investigate the affinity in liberality, undecidability, iterability, khōra, and the text itself. In A Knight of the Seven Kingdoms, these concepts influence each other so that it shows the liberal aspects of literary works. This is shown through the structure in the narrative of A Knight of the Seven Kingdoms which keeps the story dynamic and the narrative, with its liberal power, constantly tests its context to eliminate certain idealistic tendencies. Thus, the identity and ideality that are considered final are again questioned and made unstable by the text to reveal more meaning and possibility produced.
\end{abstract}

Keywords: Derridean, fantasy novel, undecidability

\section{Pendahuluan}

A Knight of The Seven Kingdoms adalah novel karangan George Raymond Richard Martin yang menceritakan petualangan Ser Duncan the Tall dan Aegon V Targaryen satu abad sebelum dunia $A$ Song of Ice and Fire, novel puncak George R. R. Martin. A Knight of
The Seven Kingdom terdiri dari tiga bagian, yakni The Hedge Knight, The Sworn Sword, dan The Mystery Knight dan diterbitkan pada tahun 2015. Tokoh-tokoh di dalamnya mengalami berbagai peristiwa yang memengaruhi perangai mereka hingga akhir cerita sehingga novel ini 
mengontestasikan antara yang baik dan buruk dalam berbagai lapisan. Hal ini jamak ditemui dalam karya Martin lainnya, seperti A Song of Ice and Fire, yang telah diekranisasikan dalam bentuk serial berjumlah delapan season dari HBO yang dikenal dengan nama Game of Thrones (2011-2019). Termasuk di dalamnya satu episode bertajuk $A$ Knight of The Seven Kingdoms (episode kedua dari season 8). Pada analisis ini, juga akan ditunjukkan afinitas antara novel A Knight of The Seven Kingdoms dengan episode kedua dari season 8 Game of Thrones tersebut. Menurut Derrida (2000: 89-90), suatu struktur selalu memonitor, mengorganisasi, dan jika perlu merombak pusatnya sendiri dengan otoritasnya. Pusat tidak keluar dari struktur, tetapi merupakan bagian dari struktur yang lain. Oleh karena itu, sebagai upaya untuk mengungkap dunia, mitos, dan fantasi Martin, penelitian ini secara spesifik akan mengkaji $A$ Knight of The Seven Kingdoms dengan tiga konsep Jacques Derrida, yakni liberalitas fiksi, fiksi sebagai institusi liberal, dan the play of structure.

Martin menciptakan dunia dengan makhluk dan budaya yang kompleks. Mitologi Martin mencakup berbagai elemen, cerita, mitos, dan bahkan menggunakan nama-nama yang berasal dari budaya Yunani, Yahudi, Latin, Mesir, dan lain sebagainya. Meski demikian, narasi yang dibangun Martin tetaplah inovatif dan memiliki independensi. Contohnya terlihat dari bagaimana $A$ Knight of The Seven Kingdoms memuat berbagai kepercayaan, disposisi, ras, dan budaya untuk mengembangkan cerita fantasi. Pembacaan
Derridean (Derridean reading) memberi peluang untuk mengeksplorasi dan menganalisis komponen-komponen A Knight of The Seven Kingdoms. Dengan membahas dan mengeksploitasi istilah-istilah Derridean seperti undecidability (kemampuan untuk tidak bisa memutuskan; ketidakpastian), liberality (kebebasan), dan khōra dalam membaca A Knight of The Seven Kingdoms, penelitian ini bermaksud menunjukkan sejauh mana teks Martin memenuhi pandangan Derridean tentang fiksi sebagai institusi liberal, serta menunjukkan upaya baru dalam menganalisis novel populer.

Karakter utama A Knight of The Seven Kingdoms-Ser Duncan "Dunk" the Tall dan Aegon V "Egg" Targaryen—akan diteliti melalui konsep khōra dan bagaimana kekuatan liberal dari narasi itu sendiri merekonstruksi sosok Egg yang bertahan dengan Dunk sampai akhir perjalanan. Dengan demikian, dapat ditunjukkan bagaimana istilah-istilah Derridean (seperti iterability, alterity, undecidability, dan sebagainya) dapat menjelaskan teks-teks Martin untuk mencerminkan dan mewakili kekuatan fiksi liberal dalam A Knight of The Seven Kingdoms.

Menurut Staggs (2012: 149), meski cerita karangan Martin sering kali dibandingkan dengan The Lord of The Rings karya J. R. R. Tolkien, dunia ciptaan Martin memuat kompleksitas psikologi yang tidak ada dalam karya-karya Tolkien. The One Ring dalam The Lord of The Rings menghancurkan kebaikan manusia, sehingga dapat dipastikan hal ini merupakan pengaruh kekuatan jahat yang bersifat supranatural yang menunjukkan bahwa manusia (maupun elf, kurcaci, dan hobbit) pada da- 
sarnya adalah makhluk yang baik. Martin tidak memperkenalkan bentuk kejahatan eksternal semacam itu karena baginya, kebaikan dan keburukan ada sekaligus dalam diri subjek. Pendapat Staggs tersebut menunjukkan salah satu sebab karya-karya George R. R. Martin diakui sebagai novel fantasi yang monumental pada abad ke-21, terutama apabila disandingkan dengan novel bergenre serupa karya J. R. R. Tolkien. Martin dipercaya tidak meninggalkan formula fantasi, tetapi mengeksploitasinya guna mengonstruksi cerita yang kuat dan dapat dipahami pembaca.

He also writes brilliant characters: heroes to cheer, and too often to cry for; villains to hate, but more than that, to understand (and, perhaps, to view as the dark sides of our own natures); monsters that make you ponder that most basic and profound human fear, the one to which, alas, there is no answer. It's no secret and no accident why he's so successful. His characters are real to him, it matters not their race, and he writes them with such affection that they become real to the reader. That's the thing about fantasy. Set aside the strange trappings, erase the swirl of magic and strike the fairy-tale castles, and you have elves and dwarves and evil orcs that the author has to make, in the end, human; if the readers cannot identify with the sensibilities of these characters as they react to the pressure of their surroundings, the book, like any book shelved under any label, will fail. (Salvatore, 2012: xi).

Gaya komposisi dan narasi karya-karya Martin tampak terbuka untuk interpretasi yang berbeda sehingga mampu menciptakan makna yang berbeda untuk pembaca yang berbeda. Martin tidak merasa perlu menciptakan monster dan bentuk kejahatan lainnya, tetapi ia menggalinya dalam diri manusia, bahwa sejatinya tokoh-tokohnya pun memiliki kebaikan dan keburukan dalam diri mereka. Egg, misalnya, digambarkan sebagai calon pewaris tahta yang lemah dan gemar berbohong (Martin, 2015: 82), tetapi pada akhir perjalanannya, ia akan melepas statusnya sebagai squire dan menjadi kesatria. Inilah yang disebut dengan kompleksitas psikologi oleh Staggs di atas.

Meskipun demikian, Martin juga tetap memasukkan unsur fantasi seperti [telur] naga, three-eyed raven, kurcaci, dan lain sebagainya yang memerlukan referensi terdahulu dalam pemikiran pembaca. Referensi ini dipahami Martin, kemudian direkonstruksi dalam cerita. Young (2019) menyebut hal ini sebagai artefak literer yang harus dijelaskan dengan meminta pembaca agar memercayai pengarang untuk mengolah elemen-elemen naratifnya agar setimpal dengan upaya pembaca membayangkan hal-hal tersebut. Dengan demikian, baik pengarang maupun pembaca tak dapat sepenuhnya memaksakan suaranya pada narasi atau pembaca lain. Membaca $A$ Knight of The Seven Kingdoms akan mengungkap hubungan antara pandangan Derridean dan Martin tentang karya sastra. Dengan demikian, penelitian ini terutama didasarkan pada dua prinsip: konsep permainan struktur dan bagaimana memandang fiksi sebagai institusi liberal.

\section{Institusi Liberal}

Pertanyaan yang membedakan antara teks sastra dan non-sastra merupakan topik yang banyak disinggung. Demikian pula dengan Jacques Derrida yang memberi perhatian khusus terhadap hal ini untuk menunjukkan posisinya. Menurut Attridge (1992: 1-2), banyak pendapat yang menunjukkan bahwa perhatian utama Derrida adalah implikasi kelembagaan, 
etika, dan yuridis dari pertanyaan seperti "apa hukum yang membuat teks dianggap sastra atau bukan-sastra?" Selain itu, "siapa dan lembaga apa yang memiliki wewenang untuk menjawab pertanyaan semacam itu?" Meskipun sebuah karya sastra dipengaruhi hukum dan peraturan, ia menunjukkan kemampuan dan kekuatan untuk mengacaukan dan mengguncang aturan itu. Dengan kata lain, teks tidak mewakili apa pun di luar jaring kata-katanya, tetapi Derrida (1992: 11) menegaskan bahwa sastra bergerak melampaui jaring kata-kata, "we are before this text that, saying nothing definite and presenting no identifiable content beyond the story itself, except for an endless difference, till death, nonetheless remains strictly intangible". Melalui pendapat ini, karya Martin, sebagai produk sastra, dapat mengganggu pusatpusat dan kehadiran yang mengikutinya. Ironisnya, karya sastra tidak hanya mengganggu otoritas pusat, tetapi juga menjamin kebebasan bermain struktur. Hal ini adalah peristiwa sastra yang memungkinkan kita untuk memahami gagasan tentang struktur tanpa pusat (Derrida, 2001: 298).

Karya-karya Martin memiliki dunia di luar realitas dan dibaca oleh banyak orang. Karyakarya tersebut menawarkan berbagai argumentasi atas ideologi, teokrasi, dan logosentrisme. Hal ini disebabkan oleh kebebasan karya fiksi untuk mengangkat hampir semua isu tanpa disensor. Menurut Derrida (2005: 82), sastra adalah sebuah institusi yang penemuannya selaras dengan revolusi hukum dan demokrasi dalam konteks Eropa. Oleh karena itu, sastra dengan dalih fiksi di- perbolehkan memuat apa saja sebab ia bertindak sebagai institusi liberal. Meskipun demikian, menurut Derrida, sastra juga tak luput dari pengaruh represi. Meskipun hak untuk mengatakan sesuatu tidak pernah sepenuhnya dikonkretkan, karya sastra memiliki keunggulan untuk memungkinkan seseorang mengatakan hal-hal yang sebaliknya ditekan untuk dikatakan dalam konteks lain (Derrida, 2005: 82). Dengan demikian, sastra sebagai institusi tidak memiliki kelembagaan. Sebagai sebuah institusi, sastra memang menetapkan hukum dan aturan di dalam dirinya sendiri. Namun, kebebasan sastra memungkinkan para penulis melanggar aturan-aturan tersebut justru untuk menghasilkan lebih banyak teks.

Derrida (2000: 90-94) menegaskan bahwa selama berabad-abad, telah ada pusat-pusat dalam struktur yang mengendalikan dan memastikan kekakuan yang tidak lain adalah bayangan orisinalitas dan legitimasi ideal. Pusatpusat ini tidak memiliki hak dan keberadaan di luar struktur. Saat legitimasi pusat dipertanyakan, mereka mencoba mengganti pusat dengan yang sebelumnya untuk menutupi kelemahan dan keretakan pada otoritas pusatpusat tersebut. Oleh karena itu, akan ada "permainan" konstan dalam strukturalitas struktur. Konsep Tuhan dalam A Knight of The Seven Kingdoms menjelma menjadi The Old God dan The New God. Keduanya dikonstruksi oleh makhluk lain dan mitos pembentuk. Ia dapat berfungsi sebagai kehadiran dan penguasaan pusat yang menyeluruh. Ironisnya, seperti permainan dalam struktur yang ditekankan oleh Derrida, sepanjang narasi A Knight of The Seven Kingdoms, kemurnian, keberadaan, dan otori- 
tas pusat-pusat seperti Tuhan akan menjadi tidak stabil dan dipertanyakan.

Dalam kuliahnya di Universitas John Hopkins pada 21 Oktober 1966, Derrida membawakan materi berjudul La structure, le signe et le jeu dans le discours des sciences humaines (Structure, Sign, and Play in the Discourse of the Human Sciences) yang dipublikasikan tahun 1967 sebagai bagian sepuluh dalam Writing and Difference (L'écriture et la différence). "Structure, Sign, and Play" mengidentifikasikan tendensi para filsuf untuk mencela satu sama lain terhadap wacana problematik dan hal ini tidak terhindarkan sebab kita hanya bisa menulis dalam bahasa yang kita warisi. Mendiskusikan antropologi Claude Lévi-Strauss, Derrida menganggap bahwa kita semua adalah bricoleurs, pemikir kreatif yang harus menggunakan segala peralatan yang kita temukan di sekitar kitaDerrida mengungkapkan bahwa dasar yang kita sebut sebagai pusat (center), pengulangan, substitusi, transformasi, dan permutasi selalu diambil dari sejarah makna yang asalusulnya selalu dapat diungkapkan atau diantisipasi bentuk kehadirannya. Strukturalitas struktur pada akhirnya dikurangi dan orang berlomba-lomba untuk memahami struktur dasar kehadiran yang mana tidak dapat ditandingkan. Dengan demikian, terdapat kontradiksi dalam keinginan strukturalisme untuk menemukan struktur fundamental. Struktur fundamental, menurut Derrida, akan memberikan semacam titik tetap dalam struktur keseluruhan: asal atau pusat. Asal atau pusat ini, pada gilirannya, akan memberikan semacam keamanan bagi produksi makna secara keseluruhan melalui perbedaan.

Sebuah pusat atau asal, dengan menjadi fundamental,
tidak akan dengan sendirinya tunduk pada inter-
pretasi atau mendapatkan makna melalui perbedaan,
dan dengan demikian akan membatasi fleksibilitas
atau, sebagaimana ia menyebutnya, 'permainan'
makna dalam seluruh struktur, membatasi inter-
pretasi dan kemungkinan makna (Smith-Laing,
2018).

Karya sastra dalam pandangan Derrida merupakan institusi liberal dan mempertahankan perbedaannya; bahwa tak ada yang sepenuhnya mengikat dan tetap. Hal ini sesuai dengan A Knight of The Seven Kingdoms karya George R. R. Martin yang hingga saat ini dibaca oleh orang di seluruh belahan dunia dan dianggap sebagai karya yang terbuka sebab ia tidak hanya menyentralisasi satu ideologi. Karya sastra memanglah sebuah institusi sebab produksinya berhubungan dengan konteks lingkungan sekitarnya, tetapi dalam bingkai fiksi, karya sastra bebas menyuarakan apa saja, terutama yang dibatasi dalam lini lainnya. Oleh sebab itu, A Knight of The Seven Kingdoms sebagai institusi dapat juga tanpa-institusi sebab aturan dan hukum di dalamnya memberikan kita kesempatan untuk mengubah dan membelokkan karya tersebut.

\section{Undecidability dalam A Knight of The Seven Kingdoms}

A Knight of The Seven Kingdoms diawali dari kisah seorang squire (seorang pengawal/ pelayan) bernama Dunk. Setelah kesatria yang diikutinya, Ser Arlan of Pennytree, meninggal, Dunk mengambil alih semua barang Ser Arlan dan menamai dirinya dengan Ser Dunk. Padahal gelar kebangsawanan tidaklah diberikan 
Poetika: Jurnal Ilmu Sastra

Vol. VII No. 2, Desember 2019
DOI 10.22146/poetika.51548

ISSN 2338-5383 (print); 2503-4642 (online) sembarangan, apalagi melalui selfproclaimed. Hal ini menunjukkan bahwa dalam karya sastra, kebaruan-kebaruan selalu ditawarkan. Dalam teori Derrida, hal ini dikenal dengan konsep iterability, yakni kemampuan tanda untuk menahan referensi, untuk berarti sebaliknya, atau untuk dibaca sebagai tanda lebih dari jangkauan konteks narasinya. Derrida (1998: 53) mengungkapkan bahwa iterability bersifat diferensial, ia berada dalam masing-masing "elemen" individu maupun di antara "elemen-elemen" tersebut karena ia membongkar setiap elemen selagi mengonstruksinya. Hal ini terjadi sebab ia ditandai oleh jeda artikulatoris yang sisanya menunjukkan ketidakpenuhan kehadiran. Dengan demikian, iterability memberikan kemungkinan untuk membaca teks berulang-ulang dalam konteks yang berbeda dan belum memiliki wawasan baru tentangnya. Pengulangan tanpa akhir ini yang setiap kali baru dapat menghilangkan kekakuan dan otoritas dari pembacaan satu dimensi.

Iterability adalah konsep yang ideal dan juga menandai batas esensial dan ideal dari semua idealisasi yang setidaknya mengarah pada kemungkinan atas idealitas sehingga ia bukanlah nonideality (Derrida, 1977: 119). Dalam A Knight of The Seven Kingdoms, Dunk menunjukkan pengambilan keputusan yang mengubah hidupnya. Saat mengenakan perangkat kesatria Ser Arlan, ia berpikir untuk menghabiskan uang yang ada dengan makan dan minum sepuasnya di kedai. Namun, hal ini dapat dimaknai sebagai tanda kebebasan dan kenaikan posisinya dalam ke- hidupan yang tersegregasi.
Dunk frowned. "I'll have none of that. I am a knight, I'll have you know."
"You don't look to be a knight."
"Do all knight look the same?"
"No, but they don't look like you, either.
Your sword belt's made of rope." (Martin, 2015: 8).

\section{Awalan A Knight of The Seven Kingdoms} menjadi penunjuk signifikansi retoris: Dunk menjadi metafora penulis, sebab perjalanan dan petualangan yang diceritakan menjadi intens. Meski demikian, hanya berpegang pada kata dan bahasa juga menimbulkan masalah. Seperti pada bagian pertemuan Dunk dan Egg, di mana terjadi kesalahan penandaan. Dunk memperkenalkan dirinya sebagai (penanda) "kesatria" yang diketahui Egg dan sayangnya tidak menjelaskan apa pun kecuali rangkaian penanda lainnya.

"What's your name?"

"Dunk," he said.

The wretched boy laughed aloud, as if that was the funniest thing he'd ever heard. "Dunk?" he said. "Ser Dunk? That's no name for a knight. Is it short for Duncan?"

Was it? The old man had called him just Dunk for as long as he could recall, and he did not remember much of his life before. "Duncan, yes," he said. "Ser Duncan of..." Dunk had no other name, nor any house; Ser Arlan had found him living wild in the stews and alleys of Flea Bottom. He had never known his father or mother. What was he to say? "Ser Duncan of Flea Bottom" did not sound very knightly. He could take Pennytree, but what if they asked him where it was? Dunk had never been to Pennytree, nor had the old man talked much about it. He frowned for a moment, then blurted out, "Ser Duncan the Tall." He was tall, no one could dispute that, and it sounded puissant.

Though the little sneak did not seem to think so. "I have never heard of any Ser Duncan the Tall."

"Do you know every knight in the Seven Kingdoms, then?"

The boy looked at him boldly. "The good ones."

"I'm as good as any. After the tourney, they'll all know that. Do you have a name, thief?"

The boy hesitated. "Egg," he said.

Dunk did not laugh, His head does look like an egg. Small boys can be cruel, and grown men as well. (Martin, 2015: 23-24). 
Fakta bahwa nama Duncan diambil Dunk dari pertanyaan Egg juga menunjukkan bahwa keberadaan dirinya yang baru muncul setelah memulai perjalanan. Sebaliknya, Egg sendiri menyembunyikan identitasnya dan berdalih dengan menyebut panggilan kecilnya. Hal ini diterima Dunk sebab baginya, nama Egg memang sesuai dengan si anak. Di sini juga terdapat iterability tentang squire. Sebelumnya, Dunk adalah squire dari Ser Arlan. Dengan proporsi tubuhnya yang tinggi dan besar, squire dapat diartikan sebagai pengawal atau pelayan. Namun, ketika Egg diangkat menjadi squire Dunk, yang dimaksud adalah seorang bangsawan muda yang bertindak sebagai pelayan kesatria sebelum dirinya kelak diangkat menjadi kesatria.

Makna-makna di atas berusaha disusun melalui kata-kata sehingga tampak bahwa mereka masih menjadikan diri mereka tak bernama: menolak untuk digambarkan secara sepenuhnya dan sebenarnya. Yang tak bernama ini, dalam dunia khōra disebabkan pada kurangnya hasil pemikiran terhadap inklusi dan eksklusi mitos/logos sehingga di luar teks Martin, keputusan Egg untuk mengembara bersama Dunk tidak dapat dijelaskan. Egg yang awalnya digambarkan sebagai kanak-kanak berkepala botak rupanya adalah Aegon V Targaryen, salah satu calon pewaris tahta Westeros. Ia digambarkan sebagai individu yang termarjinalkan, seharusnya tidak pergi bertualang, tidak menjadi squire (terutama dari kesatria yang menamai dirinya sendiri), menyukai kedamaian, dan gemar berbohong. Sosok Aegon V "Egg" Targaryen dapat dikategorisasikan dalam berbagai generalisasi mitos dan logos. Hal ini didasarkan pada pandangan bahwa sebuah literatur yang melarang transendensi akan membatalkan dirinya sendiri (Derrida, 1992: 45). Maka fiksi memiliki kebebasan untuk merujuk kepada banyak makna oleh pembaca yang berbeda atau dalam konteks temporal, spasial, atau ideologis yang berbeda. Selain itu, iterability memungkinkan adanya wawasan dan bacaan baru setiap kali.

Dalam A Knight of The Seven Kingdoms, pembaca bertemu dengan Dunk dan Egg yang bertindak dan memutuskan melawan sifat, warisan, dan sejarahnya. Petualangan Dunk dan Egg ke Dorne dan the Wall merupakan sebuah tindakan revolusioner dalam arti literalnya. Keduanya menggerakkan peristiwa dan insiden sedemikian rupa sehingga mengacaukan cita-cita kemurnian di dunianya sendiri. Dari sinilah muncul konsep khōra yang saling berkorelasi dengan subjek dan undecidability. Menurut Dutoit (1995: xii), khōra yang dimaksud Derrida dituliskan secara fonemis dalam aksara Yunani $\chi \omega ́ \rho \alpha$ (khōra). Khōra adalah kata benda feminin untuk menamai figur ibu, perawat, (sesuatu yang) dapat diterima, atau pemberi jejak, sehingga Derrida sering kali menyebutnya sebagai she atau it. Khōra juga merujuk pada tempat, lokasi, wilayah, negara, sehingga terjemahannya tak pernah bisa diinterpretasikan. Senada dengan Dutoit, Wolfreys (1998: 39) mengungkapkan bahwa khōra tak dapat dideskripsikan atau direpresentasikan secara positif.

Khöra troubles all polarities, whether one is discussing proper sense/metaphorical sense, or whether the binarism is that of mythos/logos, upon which division the seriousness of philosophical discourse rest (Wolfreys, 1998: 39). 
Pendapat Wolfreys di atas menunjukkan bahwa apa yang dimaksud/dibawa khōra tergantung pada penggunaannya dalam ranah filosofi diskursus tertentu. Adapun menurut Bulhof (2000: 213), khōra tetaplah tanpabentuk, amorf, 'perawan'; ia seolah menerima apa yang dilekatkan padanya dan memberi mereka tempat. Namun, bentuk yang diterima khōra bukanlah ide, ia menjadi bentuk tak berwujud.

...interested in khōra for family reasons, not because khōra is a mother or a wet nurse, but because she/it is a cousin of deconstruction, a kin of the kin-less, of the same non-kind as what he calls 'différance'. It 'différance' is what deconstruction is all about, in a nutshell, then "khöra is its surname". To deploy a famous Platonic image: the story of khöra works like an 'allegory' of différance, each addressing a common, kindred non-essence, impropriety, and namelessness. (Derrida, 1997: 96-97).

Ketertarikan Derrida pada khōra bukanlah karena perannya sebagai ibu atau perawat, tetapi karena khōra merupakan kerabat dekat dekonstruksi. Dekonstruksi adalah tentang différance, sementara khōra adalah aspek yang otomatis melekatinya. Ia meyakini citraan Platonis bahwa khōra bekerja seperti alegori atas différance untuk membahas hal yang umum dan mengungkapkan ketidakwajaran serta ketanpanamaan.

Dalam A Knight of The Seven Kingdoms, setelah Trial of Seven, daripada tinggal di Ashford dan bekerja pada keluarga Targaryen, Dunk memilih berkelana dan membawa serta Egg yang diangkatnya menjadi squire. Keputusan Dunk untuk pergi berkelana mustahil dijelaskan dalam mitos/logos, maka hal ini termasuk dalam ranah khōra. Segala tantangan dan petualangan yang tidak diketahui menyebabkan Dunk mengambil keputusan tersebut. Pengambilan keputusan dan alasan serta status subjek untuk mengambil keputusan tersebut adalah bagian dari transisi yang dipengaruhi khōra, di mana subjek melakukan atau lahir dari usaha pengambilan keputusan yang tidak pasti (undecidable).

Therefore, khōra is a hybrid realm of paradoxes. Like khöra, searching for an origin of subject/ivity, whether psychological, ideological, political, mythological, or so forth, is the ultimate search for the beginning of all beginnings (Derrida, 1991: 109).

Pertemuan antara Dunk dan Egg melalui percakapan sederhana di antara mereka dan dilanjutkan dengan kejadian menggemparkan di Ashford memicu Dunk untuk mengambil keputusan yang tidak dapat dijelaskan oleh logika logos atau mitos di balik dunia Martin atau yang berada di luar teks. Sebagai contoh, jika taat pada identitasnya, Dunk tidak akan melakukan petualangan berbahaya. Ia akan tahu batas-batas dunianya dan akan menyerah pada takdir yang mengandaikan setiap rakyat jelata hidup apa adanya, tidak ingin tahu, dan tertarik pada isolasi serta kenyamanan. Maka dari itu, timbul implikasi yang membuat Dunk menjadi subjek yang terpinggirkan. Dunk dapat dikategorikan dalam banyak generalisasi yang tersirat oleh logos dan mitos.

Menurut Reynolds (2004: 46), undecidable adalah sesuatu yang tidak dapat mengonfirmasi maupun menolak polaritas dikotomi (hadir/ tidak hadir, obat/racun, dan di dalam/di luar). Derrida menyatakan bahwa dalam semua teks pasti ada titik ketidakpastian yang mengkhianati makna stabil yang mungkin ingin diterapkan pengarang pada teksnya. Perilaku Dunk menunjukkan bahwa negosiasi yang konstan mampu mengembangkan emosi-emosi, 
pembentukan alasan, dan tradisi-tradisi logosentris/mitosentris sehingga mengarah pada tahapan undecidability, di mana subjek tercipta setelah pilihannya dibuat dan bukan sebelumnya. Dengan demikian, undecidability dan khōra tak dapat dilepaskan serta bersama keduanya menggugat historisitas yang kaku melalui subjek yang independen dari struktur tersebut.

Momen Dunk mengenakan semua perangkat kesatria Ser Arlan menjadi metafora Martin yang memutuskan untuk menulis tentang seorang kesatria yang kelak akan menjadi pelindung Seven Kingdoms. Tidak hanya Dunk, hampir semua karakter dalam $A$ Knight of Seven Kingdoms memiliki warisan dan tradisi budaya, sejarah, keilahian, dan etik politik (seperti hak kebangsawanan untuk memerintah yang lebih rendah). Warisan ini membawa bayangan idealitas. Bayangbayang yang paling sederhana contohnya seperti klaim bahwa seseorang tak bisa menunjuk dirinya sendiri sebagai kesatria, seorang putra mahkota tak boleh berkelana tanpa pengawalan khusus, sesama anggota keluarga harus saling menolong dan mendukung satu sama lain, dan sebagainya. Dalam struktur kehidupan $A$ Knight of The Seven Kingdoms, muncul celah di mana bayangbayang idealitas yang dipaksakan tersebut dapat diruntuhkan.

Dari narasi $A$ Knight of Seven Kingdoms yang menggambarkan khōra dan undecidability, perlawanan antara yang dianggap baik dan buruk membuat legitimasi diri dan kemurnian karya sastra dipertanyakan. Segala sesuatu yang dilekatkan pada diri sendiri (seperti kemurnian dan wewenang) merupakan hal yang perlu didestabilisasi. Oleh sebab itu, dibutuhkan alterity (perubahan).

Derrida is an advocate for alterity, attentive to the ways in which philosophical systems like phenomenology marginalize that which is other, and more importantly, the way in which this translates into social and political practices (Smith, 2005: 38).

Ketika Ser Arlan meninggal, Dunk tergiur dengan sebuah petualangan; dia teralienasi dari dirinya, rumahnya, dan bahkan petualangan itu sendiri. Alterity terjadi ketika Dunk menjalani petualangannya. Alterity mengizinkan terjadinya fluktuasi ruang, waktu, dan subjektivitas. Ruang dan waktu yang konstan dalam hidup Dunk berubah, dan tahu-tahu ia terjerumus dalam petualangan yang melibatkan keluarga-keluarga bangsawan tua yang secara langsung maupun tidak langsung memerintah Westeros. Hal ini juga dialami Egg. Egg bisa saja tetap tinggal di Summerhall dan menjadi squire kesatria lainnya, tetapi ia mencoba mendewasakan dirinya dengan mengakrabi segala pelosok Westeros yang kelak dipimpinnya. Selain Dunk dan Egg, subjeksubjek lain dalam A Knight of the Seven Kingdoms, seperti Maekar Targaryen, Ser Eustace, dan Lord Butterwell, menahan alterity dan mencoba tetap berada dalam kemurnian.

Maekar sebagai ayah Aerion dan Aegon "Egg" Targaryen merupakan seorang pangeran dan memilih bertahan dalam posisinya sebagai pusat dengan meruntuhkan siapa saja yang menentang keluarga maupun kerajaannya. Ia tak menerima sanggahan dari orang asing, terutama yang tidak jelas asal-usulnya, dan sertamerta berpihak pada putranya meski Aerion salah (Martin, 2015: 84). Ia akhirnya mengakui 
kemampuan Dunk dan menganugerahinya gelar kesatria untuk melatih Aegon setelah terlebih dahulu menyingkirkan Aerion. Dengan demikian, meski sempat membahayakan nyawa putranya sendiri, nama besar Maekar sebagai pangeran tidak akan ternodai tatkala ia mengakui Dunk. Ser Eustace adalah bangsawan tua yang menghormati sejarah dan hampir selalu menyimpulkan keputusan atas nama orang lain (Martin, 2015: 156157). Daripada mengambil risiko, Ser Eustace lebih suka memilih jalan tengah ketika menghadapi permasalahan. Demikian pula Lord Butterwell yang menolak disertakan dalam segala kekacauan yang dialami Dunk dan Egg karena ketakutannya akan Maekar Targaryen (Martin, 2015: 331). Berbeda dengan Maekar Targaryen, baik Ser Eustace maupun Lord Butterwell menghindari peperangan terbuka dan lebih senang menyelesaikan segala sesuatu secara diam-diam dan apa adanya. Mereka tak sedikit pun mengangkat pedang untuk membela kebenaran sebab takut kehilangan posisinya yang penting dalam kebangsawanan. Dengan demikian, subjek-subjek tersebut mencoba untuk naik ke puncak strukturalitas yang terkait dengan logos/mitos serta membenarkan bayangbayang otoritas mereka dengan menggunakan ontologi seperti budaya, sejarah, dan keturunan.

Derrida privileges a conception of responsibility toward alterity that involves respecting the aspects of the other that resist being known, and that resist being transformed or altered through interaction with the self, or subject, who is attempting to be responsible toward the other (Reynolds, 2004: xvii).

Melalui alterity, subjek-subjek dalam $A$
Knight of The Seven Kingdoms dapat bergerak untuk menyembunyikan diri dan menolak diubah melalui interaksi yang semata-mata berusaha tampak bertanggung jawab terhadap orang lain. Dalam narasi Martin, A Knight of the Seven Kingdoms adalah upaya untuk menemukan pribadi yang penuh dengan pergulatan mempertentangkan kekuasaan, kemurnian, dan legitimasi yang tak terbantahkan.

\section{Hibriditas dan Liberalitas Subjek}

Dunk tidak seharusnya melakukan petualangan sebagai kesatria dan melawan keluarga bangsawan, tetapi ia akhirnya memperjuangkan nasibnya sendiri. Sementara Egg yang masih anak-anak juga tidak seharusnya ikut berkelana sebagai pengikut seseorang yang bukan-kesatria. Hal ini menunjukkan kemampuan karya sastra sebagai institusi tanpa kelembagaan yang bisa mengangkat wacana apa pun dan menggerakkannya ke mana saja. Dunk, meskipun bertubuh perkasa, bukanlah jelmaan karakteristik pahlawan pada umumnya, ia sendiri mengakui dirinya sebagai subjek yang berpikir sederhana, ia awalnya hanya berharap untuk merasakan menjadi seorang kesatria yang memiliki uang. Namun, negosiasi lingkungan dan hasratnya membuatnya melakukan petualangan dan meninggalkan tawaran menggiurkan. Hal ini membuatnya hybrid; ia bisa menjadi kesatria sekaligus bukankesatria.

Bertemu dengan Egg (yang dikiranya sebagai anak pengurus kandang kuda), membuat Dunk menjumpai dirinya yang-Lain. Meski tak memahami Egg, Dunk harus tetap berurusan dengannya. Terutama setelah menyadari kecer- 
Poetika: Jurnal Ilmu Sastra

Vol. VII No. 2, Desember 2019
DOI 10.22146/poetika.51548

ISSN 2338-5383 (print); 2503-4642 (online) dasan Egg dalam mengenali bangsawanbangsawan terkemuka dan para kesatria. Dunk yang selama ini hidup sebagai pengawal rendahan merasa perlu mempelajari hal tersebut guna menjadi kesatria seutuhnya.

Egg chattered all through their breakfast, talking of this man and that man and how they might fare. He was not japing me when he said he knew every good knight in the Seven Kingdoms, Dunk thought ruefully. He found it humbling to listen so intently to the words of a scrawny orphan boy, but Egg's knowledge might serve him should he face one of these men in a tilt (Martin, 2015: 52).

Dunk tanpa sadar berharap bisa menghilangkan sikap bukan-kesatria dalam dirinya yang berusaha menjalani hidup dengan semestinya. Oleh sebab itu, Egg merupakan diri yang-Lain yang dapat membantunya. Sosok Egg memang digambarkan lemah dan baru memiliki kekuatan dengan nama besar keluarganya. Dunk bisa saja mencampakkan Egg dalam petualangannya, tetapi ia malah mengangkat Egg yang inkompeten menjadi squire dalam perjalanan yang berat. Saat itulah, Dunk masuk dalam hibriditas lainnya. Meskipun Egg berperan sebagai squire, kondisi fisik dan psikologisnya membuatnya bergantung sepenuhnya pada Dunk.

The lad looked to be no more than eight or nine, a pasty-face, skinny thing, his bare feet caked in mud up to the ankle. His hair was the queerest thing about him. He had none. (Martin, 2015: 8)

The meadow was a churning mass of people, all trying to elboy their way closer for a better view. Dunk was as good an elbower as any, and bigger than most. He squirmed forward to rise six yards from the fence. When Egg complained that all he could see were arses, Dunk sat the boy on his shoulders. (Martin, 2015: 52)

Bahkan pada bagian The Mystery Knight, identitas Egg yang terbongkar membuat
Dunk dikepung dan membunuh Black Tom Heddle, menantu Lord Butterwell. Hal ini sekaligus membuat Egg sebagai "musuh yangLain" bagi Dunk. Ia seharusnya menjauhi Egg untuk menyelamatkan nyawanya, tetapi berakhir melindungi Egg mati-matian hingga diangkat sebagai kesatria pelindung Seven Kingdoms. Hal ini menunjukkan bahwa sebagai teks, Dunk punya kekuatan yang membebaskan dan merusak aturan mitosentrisnya.

Perjalanan Dunk dan Egg tersebut sebenarnya berlangsung tanpa tujuan spesifik. Keduanya bertualang berkeliling Westeros dan menghadapi berbagai rintangan yang mengancam nyawa mereka. Seperti pertarungan Trial of Seven antara Dunk dengan Aerion Targaryen di Ashford, pertarungan Dunk dengan Ser Lucas Inchfield di Standfast, serta pertarungan di Whitewalls. Dunk yang memiliki keahlian bertarung dan bermain pedang menjadi tokoh utama yang bertindak sebagai pahlawan demi kehormatannya. Hal ini terjadi terutama karena Dunk berhadapan dengan keluarga bangsawan tua yang angkuh dan menjunjung kemuliaan garis keturunan.

My brother Maekar returned to the castle a few hours
ago. He found his heir drunk in an inn a day's ride to
the south. Maekar would never admit as much, but I
believe it was his secret hope that his sons might out-
shine mine in this tourney. Instead they have both
shamed him, but what is he to do? They are blood of
his blood. Maekar is angry, and must needs have a tar-
get for his wrath. He has chosen you (Martin, 2015:
82).

Perselisihan antara Dunk dengan Aerion Targaryen sampai ke telinga ayah Aerion dan Aegon, Maekar Targaryen. Aerion memfitnah Dunk di depan ayahnya sehingga membuat Dunk terpaksa memilih trial by combat. Aerion 
meminta pertarungan tersebut diadakan antarkesatria berkuda dengan tujuh lawan tujuh (Trial of Seven). Di sini ditunjukkan dalam ucapan Baelor Targaryen bahwa meskipun kesalahan terletak pada anak-anaknya, Maekar tidak akan mengakui kesalahan apalagi meminta maaf. Konsep kesatria yang dikenal Maekar tidak mengizinkan adanya sikap bimbang apalagi mundur setelah mengambil keputusan. Namun, ia sendiri yang menghampiri Dunk setelah Dunk memenangkan pertarungan.

Aegon is to return to my castle at Summerhall. There is a place there for you, if you wish. A knight of my household. You'll swear your sword to me, and Aegon can squire for you. While you train him, my master-at-arms will finish your own training (Martin, 2015: 116).

Dengan demikian, dalam $A$ Knight of The Seven Kingdoms, bentuk-bentuk kemurnian dipertanyakan tanpa mendegradasi tokohtokoh tertentu. Seperti Dunk yang memilih jalan takdirnya sendiri, Egg yang memuja Dunk, dan Maekar yang menganggap kesalahan Dunk tuntas dengan cara kesatria. Martin memberikan suara tersendiri pada subjek dan karakternya sehingga sesuatu yang awalnya tampak tak terkalahkan, benar-benar asli, dan sepenuhnya hadir dalam "diri", secara bertahap dirombak dalam permainan struktur. Diri sebagai bentuk keabsahan pusat tersebut dipertanyakan dan ditantang oleh narasinya sendiri. Oleh sebab itu, kekuatan terbesar teks ini terletak pada kenyataan bahwa ia bergerak secara bebas melampaui wacana-wacana lain. Hal ini mengarahkan kita pada serial Game of Thrones episode kedua season ${ }^{2}$ yang berjudul
A Knight of The Seven Kingdoms. Beranjak seratus tahun dari dunia A Knight of The Seven Kingdoms karya Martin, dalam serial ini diceritakan keadaan Westeros yang kacau balau: Iron Throne diduduki Cersei Lannister setelah suami dan ketiga anaknya tewas; The North dipimpin Sansa Stark yang bertemu kembali dengan saudara-saudaranya (Arya, Bran, dan Jon Snow); serta Daenarys Targaryen-cucu dari Aegon V "Egg"-yang berusaha merebut kembali tahta Westeros.

Sosok yang dirujuk sebagai kesatria dari Seven Kingdoms adalah Brienne of Tarth, seorang perempuan bertubuh tinggi besar yang ahli bermain pedang dan berperang. Meski berasal dari keluarga Tarth, Martin mengimplikasikan bahwa Brienne memiliki hubungan darah dengan Ser Duncan the Tall, sebab selain keduanya bertubuh tinggi, Brienne ditampakkan membawa perisai yang dulu dimiliki Ser Duncan. Dalam episode ini, Brienne dianugerahi gelar kesatria oleh Jaime Lannister, yang membuatnya sebagai Ser Brienne. Dengan demikian, julukan 'a knight of The Seven Kingdoms'-yang awalnya ditujukan Martin terhadap Ser Duncan the Tall (satu-satunya kesatria pada masanya yang memberi gelar pada dirinya sendiri kemudian diakui oleh keluarga-keluarga bangsawan di Westeros)berevolusi untuk Ser Brienne of Tarth sebagai satu-satunya kesatria perempuan di Westeros. Dengan demikian, dalam karya-karyanya, Martin menunjukkan bahwa entitas tertentu seperti logos bertindak saling menggantikan secara terus-menerus sehingga mereka tidaklah stabil. 
Poetika: Jurnal Ilmu Sastra

Vol. VII No. 2, Desember 2019
DOI 10.22146/poetika.51548

ISSN 2338-5383 (print); 2503-4642 (online)

\section{Simpulan}

Penelitian ini mengungkapkan bahwa dalam A Knight of The Seven Kingdoms, George R. R. Martin menciptakan bayang-bayang tentang struktur yang tidak murni dengan mengakui pribadi subjek yang memiliki suara tersendiri. Di dalam proses perubahan akibat peristiwa yang dialami subjek, terdapat kekuatan yang membuat narasi bergerak maju dengan bebas (Lalbakhsh dan Ghaderi, 2017: 165-166). Dengan demikian, A Knight of The Seven Kingdoms senada dengan pandangan Derridean, bahwa karya sastra adalah institusi liberal. A Knight of The Seven Kingdoms juga menunjukkan bahwa identitas yang hibrid dan subjek pinggiran juga tidak luput dari klaim logos dan mitos, meski akhirnya mendekonstruksinya seperti yang tampak pada Dunk dan Egg. Lebih jauh lagi, tokoh-tokoh bangsawan bahkan dalam novel populer tetaplah menjunjung kemurnian dan bersikap mahakuasa sehingga ditantang oleh perubahan narasi yang ada. Kekuatan dan identitas mereka dipertanyakan oleh subjek terpinggirkan seperti Dunk. Oleh karena itu, kekuatan terbesar teks terletak pada fakta bahwa ia bergerak secara liberal melampaui wacana lain.

Dengan kekuatan teks fantasi, liberalitas untuk menciptakan dunia yang jauh dan independen dari dunia yang sebenarnya, menemukan potensi yang lebih besar untuk mengatakan bahwa tidak semua penulis sepenuhnya bertanggung jawab atas apa yang dituliskan. Penulis membiarkan narasi tetap terbuka agar pembaca dapat menandai dan mengisi makna-makna di dalamnya. Untuk melakukannya, Martin memperkenalkan entitas seperti logos yang saling menggantikan sehingga menunjukkan ketidakstabilannya. Halhal inilah yang dijawab dalam pembacaan dengan perspektif Derridean atas A Knight of The Seven Kingdoms karya George R. R. Martin.

\section{Daftar Pustaka}

Attridge, Derek. 1992. "Derrida and the Questioning of Literature" dalam Jacques Derrida dan Derek Attridge (Ed.). Acts of Literature. New York: Routledge.

Bulhof, Ilse N. 2000. "Being Open as a Form of Negative Ideology" dalam Ilse N. Bulhof dan Laurens Ten Kate (Ed.). Flight of the Gods: Philosophical Perspectives on Negative Theology. New York: Fordham University Press.

Derrida, Jacques. 1977. Limited Inc. Terjemahan oleh Samuel Weber dari Limited Inc $a b$ c... (1972). Evanston: Northwestern University Press.

York: Routledge. 1992. Acts of Literature. New 1997. Deconstruction in a Nutshell: A Conversation with Jacques Derrida. New York: Fordham University Press.

2000. "Structure, Sign, and Play in the Discourse of the Human Sciences". Dalam D. Lodge \& N. Wood (Ed.). Modern Criticism and Theory: A Reader. London: Pearson Education.

Dutoit, Thomas. 1995. "Translating the Name?" Dalam Jacques Derrida. 1995. On the Name. California: Stanford University Press.

Lalbakhsh, Pedram dan Ali Ghaderi. 2017. "The Undecidable Quest: A Derridean Reading of Tolkien's The Hobbit". Dalam Pertanika Journals 25 (1): 149-168.

Martin, George R. R. 2015. A Knight of The Seven Kingdoms. London: Harper Voyager.

Reynolds, Jack. 2004. "Decision" dalam Jack Reynolds dan Jonathan Roffe (Ed.). Understanding Derrida. London: Continuum. 2004. Marleau-Ponty and Der- 
rida: Intertwining Embodiment and Alterity. Ohio: Ohio University Press.

Salvatore, R. A. 2012. "Stories for the Nights to Come" dalam James Lowder (Ed.). Exploring George R.R. Martin's "A Song of Ice and Fire". Dallas: BenBella Books.

Smith, James K. A. 2005. Jacques Derrida: Live Theory. London: Continuum.

Smith-Laing, Tim. 2018. Jacques Derrida's Structure, Sign, and Play in the Discourse of Human Sciences. London: Macat International Limited.
Staggs, Matt. 2012. "Petyr Baelish and the Mask of Sanity" dalam James Lowder (Ed.). Exploring George R.R. Martin's "A Song of Ice and Fire". Dallas: BenBella Books.

Wolfreys, Julian. 1998. "Justifying the Unjustifiable: A Supplementary Introduction, of sorts" dalam Julian Wolfreys (Ed.). The Derrida Reader: Writing Performances. Lincoln: University of Nebraska Press.

Young, Joseph Rex. 2019. George R. R. Martin and the Fantasy Form. New York: Routledge. 